\title{
CONTRAFACTA OF OPERATIC ARIAS AMONG THE DOMINICANS OF BAROQUE SILESIA
}

\author{
TOMASZ JEŻ \\ Uniwersytet Warszawski
}

Izvleček: Razprava obravnava kontrafakturno prakso v rokopisih Piusa Hanckeja, dominikanskega meniha iz Šlezije. Njegove partiture kažejo poti, po katerih se je širil operni repertoar, in dokumentirajo procese sprememb $v$ prehodu $k$ drugi družbeni vlogi, ki jo je posamezno delo dobilo ob priredbi posvetne vsebine liturgičnemu okolju.

Ključne besede: dominikanci, kontrafaktura, operne arije, baročna glasba.
Abstract: The paper discusses contrafactum practice in the manuscripts of Pius Hancke, a Dominican monk from Silesia. His scores point to pathways for the dissemination of the operatic repertory and document the process of change in its social function associated with the adaptation of secular music to a liturgical context.

Keywords: Dominicans, contrafactum, operatic arias, Silesia, Baroque music.

The historical process of the dissemination of repertoire can be traced in a variety of ways. An analysis of the extant collections of musical prints brings out the potential, passive aspect of reception, the practical profile and active shape of which is more clearly revealed by manuscript sources. An even more successful reconstruction of the itineraries of musical repertoire can be made from music collections that are homogeneous in provenance. A given centre's own stockpile of music offers a glimpse into this collection's specificity and allows one to posit certain research hypotheses. Especially valuable in this regard are collections formed by an individual musician actively involved in local musical life. This musician's activity normally comprises a unique, personal selection of elements from the universal tradition, but with the possibility (to a greater or lesser degree) of their creative adaptation to local needs and conditions.

If we accept that the process of adaptation is the essence of musical tradition, a certain relativization has to be imposed on the idealistic conception of a creativity that is fully original and completely independent of its context, genesis and material. In turn, this revaluation becomes welcoming towards artistic adaptation, recomposition and transfiguration: after all, we consider these techniques to be immanent elements in every living culture. It is true that these elements are often pushed into the background as being phenomena of lesser importance. However, they were of key importance for the musical traditions 
of modern Europe, and they significantly influenced how culture was practised, shaping not only the style of the musical performance but also its techniques, genres and forms.

Among the most symptomatic techniques of adapting musical repertoire was that of contrafactum, which was present in European culture from the earliest times but achieved particular prominence in the sixteenth century. ${ }^{1}$ It enjoyed great popularity in religious communities actively engaged in the Reforms of Catholicism around the time of the Council of Trent. Descending into paradoxical oxymoron in the face of the Council's postulate of nihil lascivium aut impurum, ${ }^{2}$ they promoted the popular repertoire of secular music in a new, religious attire. Although this mostly affected the vernacular repertoire, the latter was able also to enjoy a parallel liturgical function. ${ }^{3}$ The justification for its admittance was expressed as a need to compete with the repertoires of other confessions - a need that quickly gained a crushing dominance in the confessional confrontations of that period. ${ }^{4}$

The practice of travestimento spirituale did not arouse any immoderate dissent on the Catholic side, the representatives of which even found for it a theological justification that attributed the sacred character of music solely to the verbal text attached to it. ${ }^{5}$ So open-minded an approach to the secular repertoire set out the directions of musical development within many Catholic communities and conferred a markedly adaptive profile on the traditions they shaped. The consequence of such a stance was a pressure to make the music performed in churches approach the style of theatrical music, and to encourage the use of actual operatic repertoire in contrafactum guise.

Numerous testimonies to this development may be found in musical manuscripts of Silesian provenance copied in the Dominican monasteries of the region. Contrary to the intermittently renewed rules prohibiting the performance of secular repertoire in the liturgy, ${ }^{6}$ this music is indeed dominated by contrafacta of popular operatic arias. This same profile is revealed by a collection of music manuscripts collected by a certain Pius Hancke (1711 or 1715-1798), who 1734 entered a Dominican monastery and 1737 took religious vows and holy orders. He was active in several cities of Silesia: in Breslau (Wrocław), Oppeln (Opole) and especially Neisse (Nysa), where he lived during the years 1764-1789 as superior and leader of the ten-strong music ensemble active at the local church of St Dominic. ${ }^{7}$ This monk was undoubtedly well trained in music, and his cultivation of the harp is suggested by the parts for this instrument added to many of his transcriptions. His inclinations toward secular music are perhaps to be explained by his earlier employment at the Larisch Palace in Groß Stein (Kamień Śląski), where he served as chaplain in the years $1756-1757 .{ }^{8}$

Among the manuscripts bearing the inscription Rerum Fratris Pij Hancke, the most intriguing are thirteen that transmit fifteen operatic arias by such composers as Giovanni

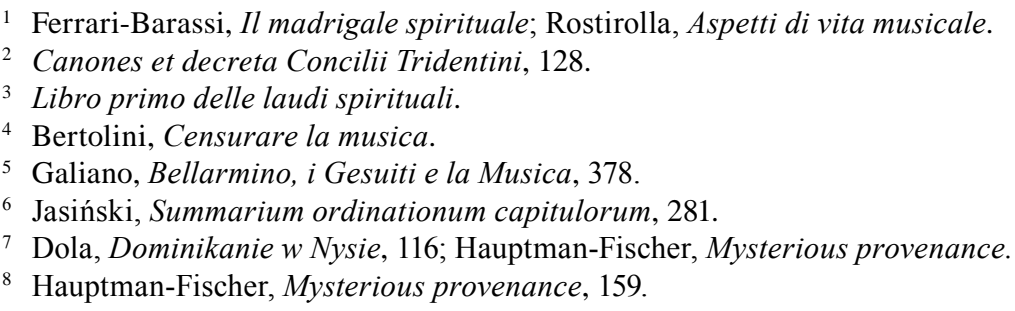


(or Antonio Maria) Bononcini (1), Francesco Antonio Feo (1), Baldassarre Galuppi (1), Geminiano Giacomelli (3), Carl Heinrich Graun (4) and Johann Adolf Hasse (5). The multifarious ways in which they are written down allows closer examination of the travestimento spirituale technique as applied in practice, documents the phenomenon of the proliferation of the operatic repertoire characteristic of the time, attests to the gradual transformation of its social function and symbolic meaning and, finally, enables a reconstruction of the consecutive stages of the assimilation of secular repertoire within the tradition of church performance. A hypothetical reconstruction of this process is the main aim of the present contribution. ${ }^{9}$

The first stage was most likely represented by faithful copies of the originals: arias copied in extenso and retaining the original underlaid text and instrumental setting. An example is furnished by "Che posso dir? Consolati," identifiable as a fragment of the opera Nitocri, regina d'Egitto (1736) by Geminiano Giacomelli. ${ }^{10}$ The words of the aria, by Apostolo Zeno, offer solace to the hero in difficult times with an assurance that his virtù will triumph:

Che posso dir? Consolati:

Sorte miglior t'attende.

$\mathrm{E}$ non cercar di più.

Sa il ciel ... sa amor ... so anch'io ...

Ma taccia l'amor mio.

Vinca la tua virtù.

This text probably caught Hancke's eye because of its subject and amenability to a religiously apposite interpretation - which, in the event, was for some reason never realized. Diametrically opposite affects are expressed by another aria written down by the Dominican, which likewise retains its original form. ${ }^{11}$ This is taken from the opera Siface, re di Numidia by Francesco Antonio Feo (1723) and furnishes an example of the so-called aria di furore, which here gives expression to particularly tumultuous emotions:
Almen la parca irata
Non mi serbasse in vita;
Perfida figlia ingrata!
Donna real tradita!
Misero genitor!
Ho perso i miei sudori,
Se basta un sol momento
Di cento allori e cento
A togliermi l'onor.

9 The present paper is not concerned with an examination of the sources' provenance and transmission (interesting though these are in their own right), but instead investigates the textual and semantic relationships arising from the contrafactum techniques employed.

${ }^{10}$ Warsaw, Biblioteka Uniwersytecka (PL-Wu), RM 5529 [Mf 1533]. Diplomatic title: "MRA | Aria ex A | Canto Solo. | Violino I | Violino II | Viola | Rerum | Fratris Pij Hancke | S. Ord: Praed ${ }^{\mathrm{m}}$." ${ }^{11}$ PL-Wu, RM 4177 [Mf 54]. Diplomatic title: "N 157 | No XXV | Ariae 2 | Alto Solo | Violino 2 ${ }^{\text {bus }}$ | Viola $\mid$ Con $\mid$ Basso | Del Sigr. Bononcini | Rerum | Fratris Pij Hancke |S. Ord. Praed ${ }^{\mathrm{m}}$. - Aria Ima.” 
It is difficult to imagine a semantically appropriate religious counterpart to this text that would fit the original music equally well; perhaps this was the reason why it never moved beyond this state. However, the same manuscript includes an aria supplied with the original text, of unknown provenance, and a religious contrafactum in parallel (see Fig. 1) - a form of notation that exemplifies the hypothetical second stage in the process of reconstruction: ${ }^{12}$

Chi legge dà al mio cor

A legge sì crudel

Non è soggetto.

È lungi dal rigor

Di cruda deità

Divino oggetto.
Mater amabilis et admirabilis,

O Mater Virgo pia.

Solamen pauperum,

Juvamen miserum in agonia.

The original words of this aria take up the frequent operatic theme of the conflict between freedom and feelings; the words added below the same melody do not, however, refer directly to such dilemmas, replacing their secular content with litany-like invocations to the Mother of Jesus. Traces of motivic correspondence are found only at the level of the two texts' general topicality, juxtaposing awe before the power of love with a description of the persona's unfortunate state. At all events, a Marian theme often justified the drawing of semantic parallels, in contrafacta, between amor divinus and amor terrenus.

To represent the next stage of the travestimento, we may consider a notational form setting down the original and its contrafacta on two separate fascicles belonging to a single set of manuscripts. An example of this is supplied by the notation of Johann Adolf Hasse's popular aria "Chi non sente al mio dolore" from the opera Cajo Fabricio in its 1735 version for Venice. ${ }^{13}$ On one of the fascicles the original version of the aria (see Fig. 2a) has been copied with its text by Domenico Lalli (an interpolation in Apostolo Zeno's original text); on the other (see Fig. 2b), we find the same composition with the contrafactum text, which is revealed to be the first two stanzas of the sequence "Lauda Sion Salvatorem," ascribed to St Thomas Aquinas:

Chi non sente al mio dolore Qualche affanno dentro al core

Vada pur nei foschi orrori

Fra le fiere ad abitar.

Il mio bene, il padre, il regno

M'ha rapiti fato indegno.

Sommi Dei, se giusti siete,

Fin ponete al mio penar.
Lauda Sion Salvatorem

Lauda ducem et pastorem

In hymnis et canticis.

Quantum potes, tantum aude:

Quia major omni laude,

Nec laudare sufficis.

12 PL-Wu, RM 4177 [Mf 54]. Diplomatic title: "N 157 | No XXV | Ariae 2 | Alto Solo | Violino $2^{\text {bus }}$ | Viola | Con | Basso | Del Sigr. Bononcini | Rerum | Fratris Pij Hancke | S. Ord. Praed ${ }^{\mathrm{m}}-$ Aria 2da."

${ }^{13}$ PL-Wu, RM 4453/8 [Mf 488]. Diplomatic title: "MRA 89 | Aria de Festo | Soprano Solo | Violino $^{\text {mo }} \mid$ Violino II $^{\text {do }} \mid$ Viola $|\&|$ Basso | Del Sig: | Hasse | Rerum | Fratris Pij Hancke | S. Ord: Praed. ${ }^{\mathrm{m}} . "$ 


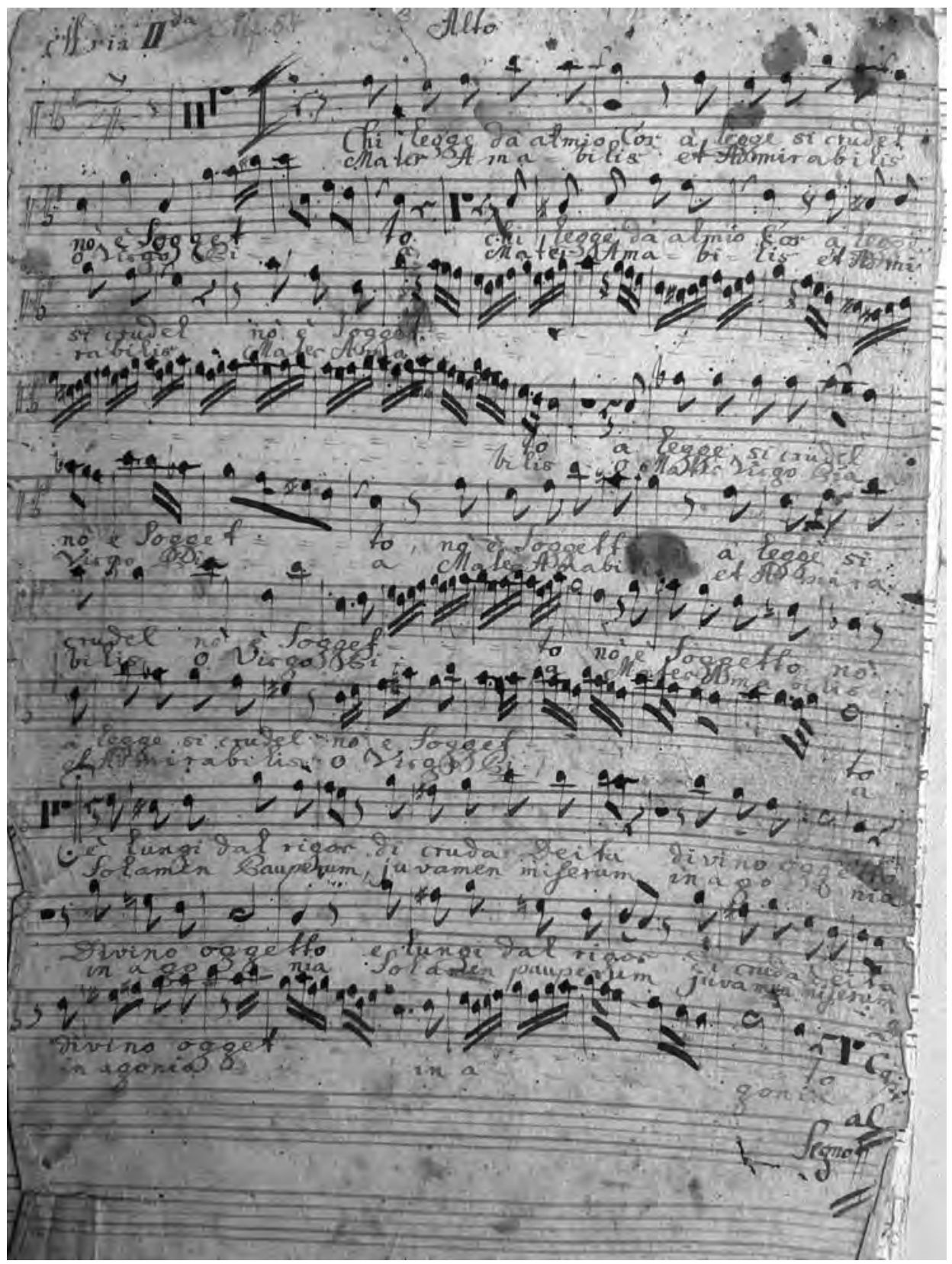

Figure 1 "Chi legge dà al mio cor" / "Mater amabilis et admirabilis" (Warsaw, Biblioteka Uniwersytecka, RM 4177; reproduced with kind permission). 


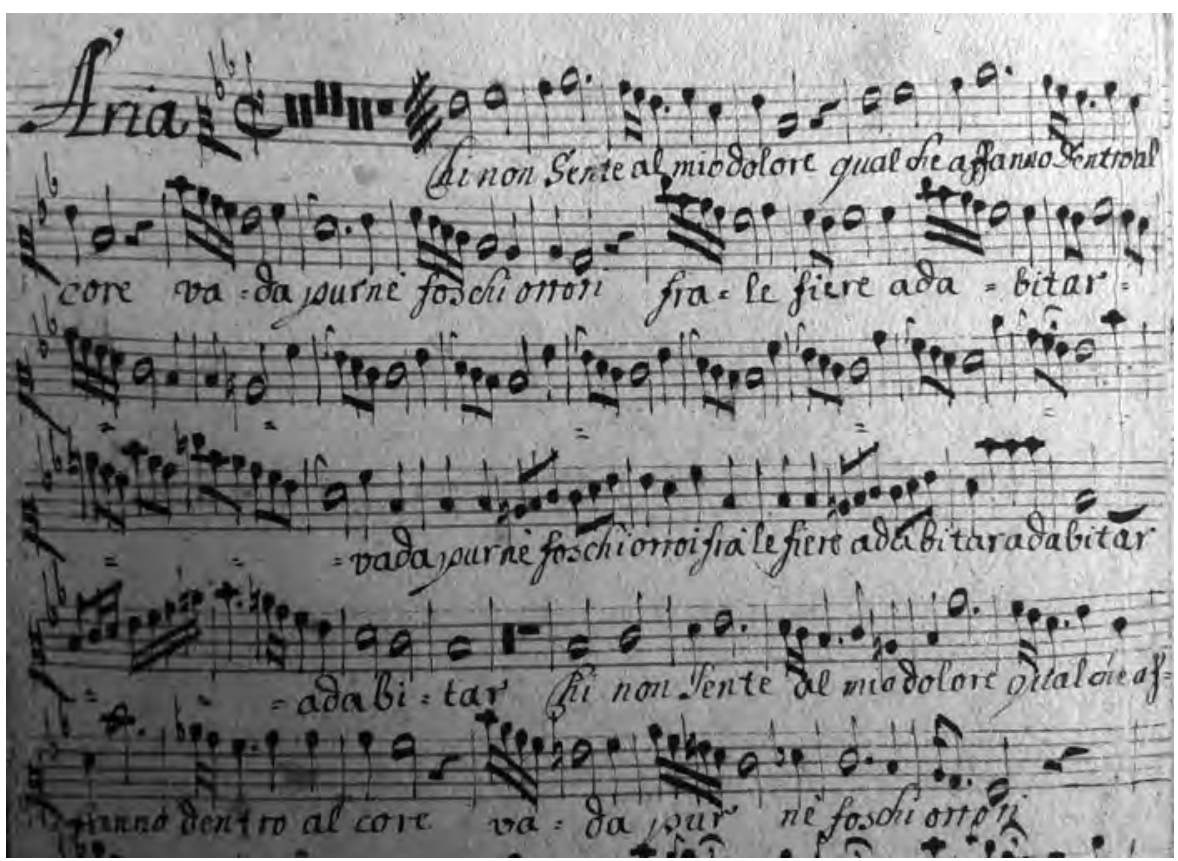

Figure 2a "Chi non sente al mio dolore" (Warsaw, Biblioteka Uniwersytecka, RM 4453/8; reproduced with kind permission).

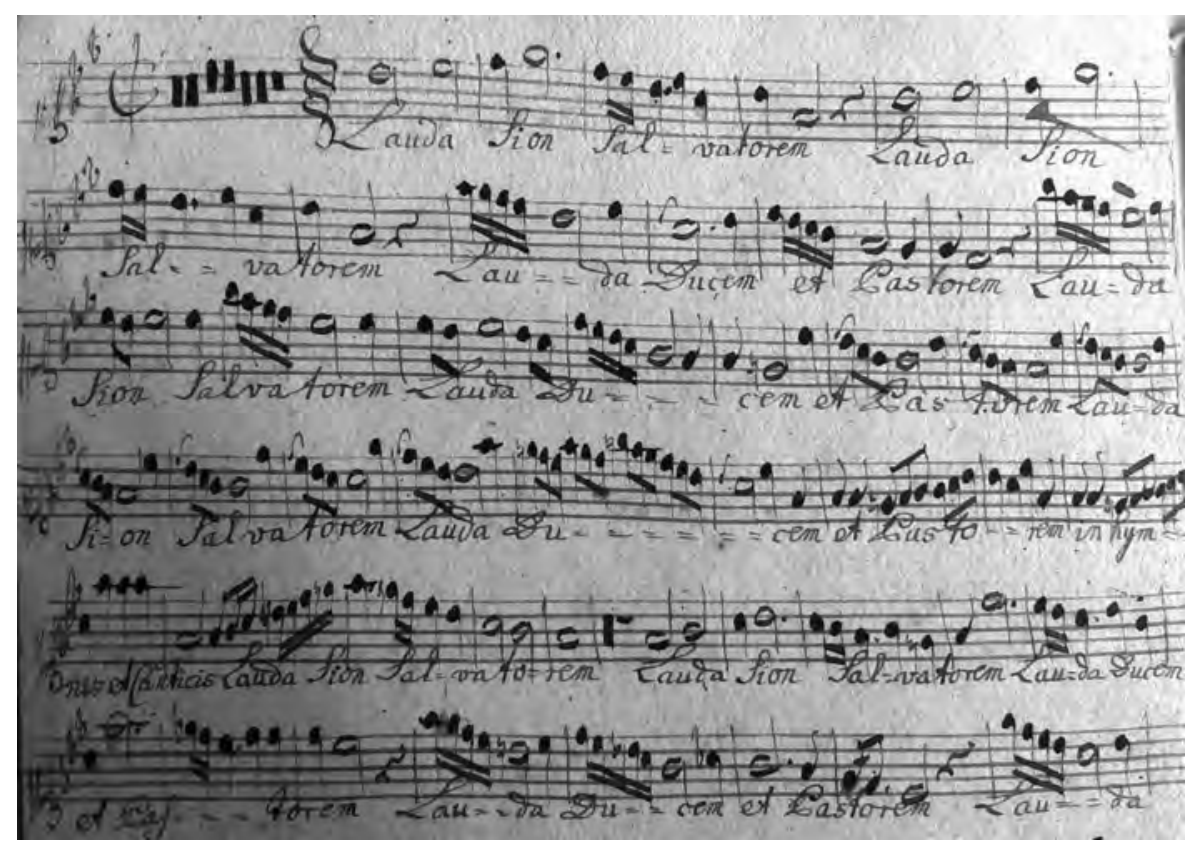

Figure 2b “Lauda Sion Salvatorem” (Warsaw, Biblioteka Uniwersytecka, RM 4453/8; reproduced with kind permission). 
The texts are completely foreign to one another in terms of both content and poetic architecture; the only similarity is found in the correspondence between the metre used and the opening with a rhyming couplet, which perhaps served as the pretext for the employment of this particular liturgical text.

A structural relationship is discernible also in the contrafactum of the aria "A trionfar mi chiama" from Hasse's opera Didone abbandonata (1742). ${ }^{14}$ Its notation represents the next stage in the process of travestimento spirituale: one that consists of setting down the original operatic melody with only the contrafactum text. Comparing it with the original, we observe a similarity on the level of textual structure; however, the symmetry is disrupted by the different accentuation pattern and disposition of rhymes. Notwithstanding this, the poems are associated by the character of their content, which makes reference to the notions of triumph and glory, illustrated - as also in the case of the Marian hymn - by the use of an obbligato trumpet:
A trionfar mi chiama
Omni die dic Mariae
Un bel desio d'onore
Meae laudes, anima;
E già sopra il mio core
Ejus festa, ejus gesta
Comincio a trionfar.
Cole devotissima.
Con generosa brama,
Ejus dona semper sona,
Fra i rischi e le ruine
Semper illa predica;
Di nuovi allori il crine
Omnes mei sensus, ei
Io volo a circondar.
Personate gloriam.

In the sole form of a contrafactum Hancke wrote down also a further aria by Hasse, taken from the opera Semiramide riconosciuta (1744). ${ }^{15}$ Here, too, the amor terrenus was made to change into religious garb, as a result of which the profession of self-sacrificing love by Ircano in Pietro Metastasio's libretto loses none of its power within the new context of prayer:

Tu sei lieto, io vivo in pene,

Ma se nacqui sventurato

Che farò? Soffrir conviene

Del destin la crudeltà.

Voi godete; io del mio fato

Vado a piangere il rigore.

Così tutta al vostro amore

Lascerò la libertà.
Magne Deus, O! Amor meus;

Te adoro Redemptorem,

Te honoro, amor mi.

Ut plus amem

Unam da scintillam,

cordi meo favillam

Tui amoris.

That practical use was made of the discussed compositions is proven by certain contrafacta of arias with an added comment about their liturgical function: for instance,

${ }^{14}$ PL-Wu, RM 4457/20 [Mf 515]. Diplomatic title: "MRA | No. IV | Aria de B.V. | Alto Solo Violinis 2bus | Clarinis 2bus | Viola et | Basso | Del Sigl: | Hasse | Rerum | Fratris Pij Hancke | S. Ord: Praed. ${ }^{\mathrm{m}}$. Hauptman-Fischer.” Mysterious provenance, 166.

15 PL-Wu, RM 4457/13 [Mf 508]. Diplomatic title: "No. 68 | Aria ex F | Tenore Solo | Violinis 2bus | Viola | \& | Basso | Del Sigl: | Hasse | Rerum | Fratris Pij Hancke | S. Ord: Praed."." 
the arrangement of the aria "Se parla l'onore" from Carl Heinrich Graun's opera Ifigenia in Aulide (1748), intended for a not more closely specified de Festo occasion. ${ }^{16}$

Ad plausus canoros,

Ad ausus sonoros

Venite, o chori.

Aulae cives, supernae aulae,

In voces veloces

Guttur distendite.

En splendet serena

Dies tam amoena

Lucem spargens per orbem

Lucem spargit per orbem et aethera.

Two other arias intended for de Tempore liturgical use appear in another manuscript: ${ }^{17}$ the first, "La fronda che circonda," from Graun's opera Catone in Utica (1744), is provided with a Eucharistic text: ${ }^{18}$

Hic Deum adorate, devoti clientes,

Et corda dicate, estote ferventes,

Deo vero Eucharistico.

Estote ferventes, devoti clientes,

Huc pia mentes convolate,

Deum vestrum adorate.

The optional final stage of the travestimento technique entailed the making of multiple contrafacta of operatic arias. This is what occurs for the aria "In te spero o sposo amato" from Graun's opera Demofoonte (1746), which in the discussed manuscript received two different contrafacta texts, notated in parallel fashion in a single musical document (see Fig. 3). The texts are linked by virtue of their similar character as a declaration of a love full of sweetness - the first addressed to the Holy Spirit, and the second to His earthly Bride and also by the fact that both are standard liturgical prose texts rather than newly written ones in verse after the manner of motets: the first belongs to an antiphon employed at First Vespers at the feast of Corpus Christi; the second, to one of the four familiar, so-called "great" antiphons sung at Compline. In both instances, the use of a pre-existing melody taken from the operatic original necessitated significant changes in order to accommodate the new texts; the length of the latter induced the author of the contrafacta to do away with the frequent repetitions, no longer needed in the composition's new, religious attire:

${ }^{16}$ PL-Wu, RM 4401/1 [Mf. 359]. Diplomatic title: "MRA | Aria | De Festo | Soprano Solo | Violinis $2^{\text {bus }} \mid$ Viola $|\&|$ Basso | Del Sigl | Graun | Rerum | Fratris Pij Hancke | Sac. Ord: Praed." ."

${ }^{17}$ PL-Wu, RM 4457/22 [Mf 517]. Diplomatic title: "Ariae de Tempore. | a | Canto | Violino Imo | Violino Secundo | Viola | con | Organo | I | Del Sigl: Hasse. | II | del Sigl: Graun | Rerum | Patris | Pii Hancke | S: Ord: Praedm."

${ }^{18}$ Hauptman-Fischer, Mysterious provenance, 166. 
In te spero, o sposo amato; Fido a te la sorte mia;

E per te, qualunque sia,

Sempre cara a me sarà.

Il piacer non sia negato

Di vantar che tua son io,

Il morir mi piacerà.
0 quam suavis est, Domine,

spiritus Tuus!

Qui ut dulcedinem tuam

in filios hominum demonstrares,

pane suavissimo

de coelo praestito,

esurientes reples bonis,

fastidioso divites dimittens inanes.
Salve, Regina, Mater misericordiae; vita, dulcedo, et spes nostra, salve. Ad Te clamamus exsules filii Hevae. Ad Te suspiramus, gementes et flentes in hac lacrymarum valle.

Eja ergo, Advocata nostra, illos tuos misericordes oculos ad nos converte.

Et Jesum, benedictum fructum ventris tui nobis post hoc exilium ostende.

0 clemens: o pia: o dulcis

Virgo Maria.

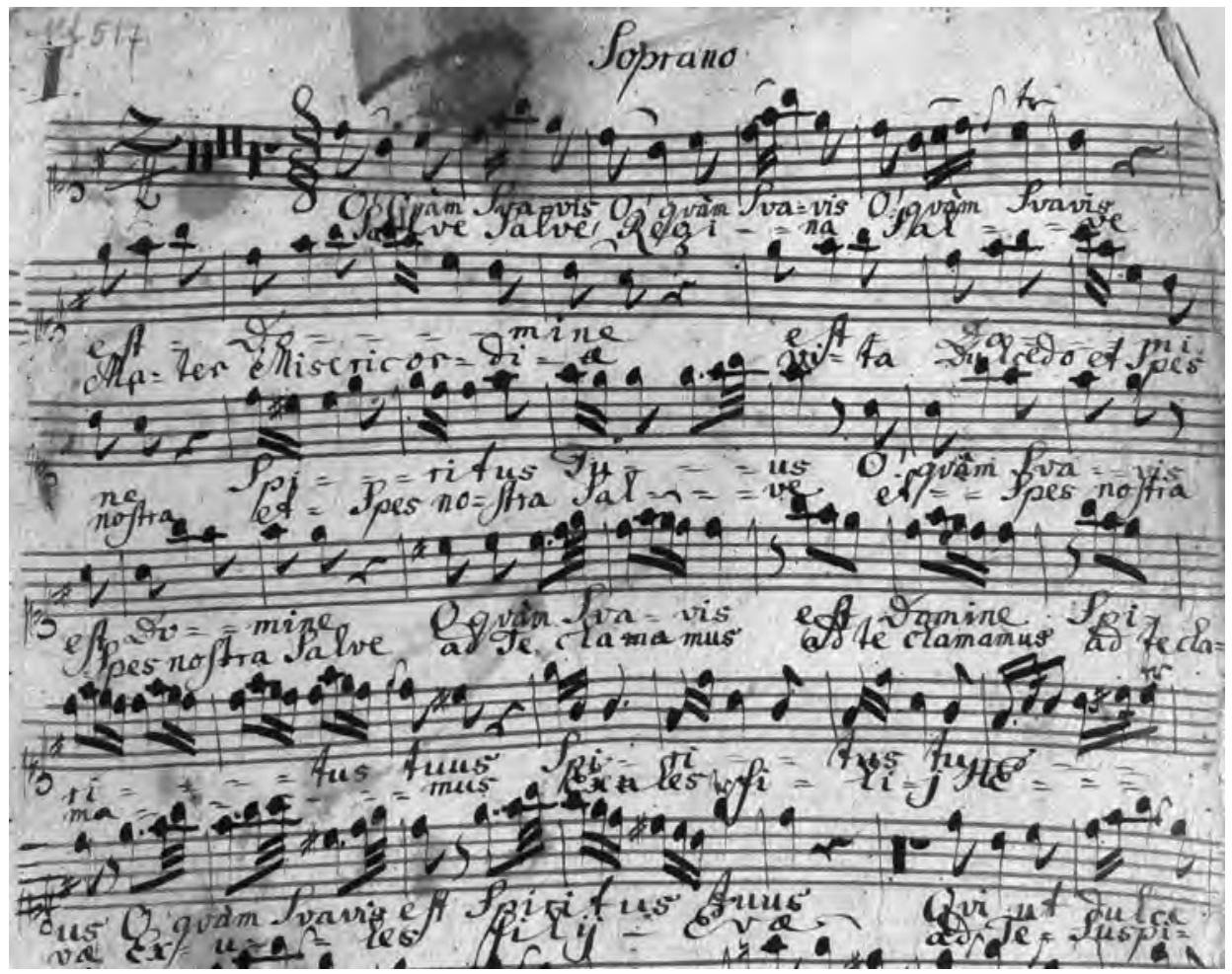

Figure 3 "O quam suavis est, Domine" / "Salve Regina" (Warsaw, Biblioteka Uniwersytecka, RM 4457/22; reproduced with kind permission).

As proof that the observed travestimento spirituale process was not accidental, we have a specific group of manuscripts from Hancke's collections in which the arrangements contain a harp part not present in the original, and which exhibit exactly the same stages of the phenomenon reconstructed above. 
Two arias by Giacomelli from the opera Nitocri, regina d'Egitto ("Non accusarmi, ingrato" and "Qual sconsolata afflitta tortorella"), ${ }^{19}$ notated with original texts in simple arrangements for soprano, violin, viola and harp, may well have been performed in secular surroundings, on the other hand. However, it is possible that written specimens of this type served only as a point of departure for contrafactum arrangements, a supposition supported by the aria "Piace la vita umile" from the same opera, which has been notated with two parallel texts: the original in Apostolo Zeno's version, and a new one appropriate for performance within the Proprium de Sanctis (see Fig. 4). Note that both texts are linked - in a rather free manner - by their assonant alliterations, discernible at least in the opening verses:

$\begin{array}{ll}\text { Piace la vita umile } & \text { Plausus hic date, } \\ \text { Al saggio agricoltor } & \text { huc properate, } \\ \text { Più del cipresso altier } & \text { Deum laudate } \\ \text { Che l'aria ingombra. } & \text { In Sanctis suis honorate, } \\ & \text { Deum invocate. } \\ \text { Da quella il frutto ei coglie } & \text { Et ipse vos exaudiet, } \\ \text { Del grave suo sudor; } & \text { Auxilium implorate. } \\ \text { Ma da questo non ha } & \text { Da, quaeso, nobis hic veniam; } \\ \text { Che onor di vane foglie } & \text { Da gratiam ut perveniamus } \\ \text { E inutil ombra. } & \text { Ad tuam gloriam. }\end{array}$

In instances where the notation includes the harp we also encounter arias set down in two versions: separately with an Italian text (see Fig. 5a) - "La dolcissima saëtta" from Hasse's opera Alfonso (1738) ${ }^{21}$ - and in a contrafactum version (see Fig. 5b) presenting the first three stanzas of the already encountered sequence "Lauda Sion Salvatorem." In this instance, however, only certain vowel alliterations associate it with Stefano Benedetto Pallavicino's original - for evident reasons, with little consistency:

La dolcissima saëtta

Nel mio sen quando vibraste

Voi di vincer m'insegnaste:

Sì, begl occhi, io vincerò.

\author{
Lauda Sion Salvatorem, \\ Lauda ducem et pastorem, \\ In hymnis et canticis.
}

Quantum potes, tantum aude:

Quia major omni laude,

Nec laudare sufficis.

Laudis thema specialis,

Panis vivus et vitalis

Hodie proponitur.

Sul rival vendicherò.

${ }_{19}$ PL-Wu, RM 5664 [Mf 1673] and RM 5665 [Mf 1674]. Hauptman-Fischer, Mysterious provenance, 165, 166.

${ }^{20}$ PL-Wu, RM 5515 [Mf 1519]. Diplomatic title: "MRA | Ariae ex G: \# | Canto Solo. | Cythara Obl: | Violino | Viola | \& | Basso | Rerum | Fratris Pij Hancke | S. Ord: Praed ${ }^{\mathrm{m}}$."

${ }^{21}$ PL-Wu, RM 5661 [Mf 1670]. Diplomatic title: "MRA | Aria ex A | Canto Solo | Harpa | Violino | Viola | et | Organo | Rerum | Fratris Pÿ Hancke | S. Ord. Praed ${ }^{\mathrm{m}}$.” Hauptman-Fischer, Mysterious provenance, 163, 166. 


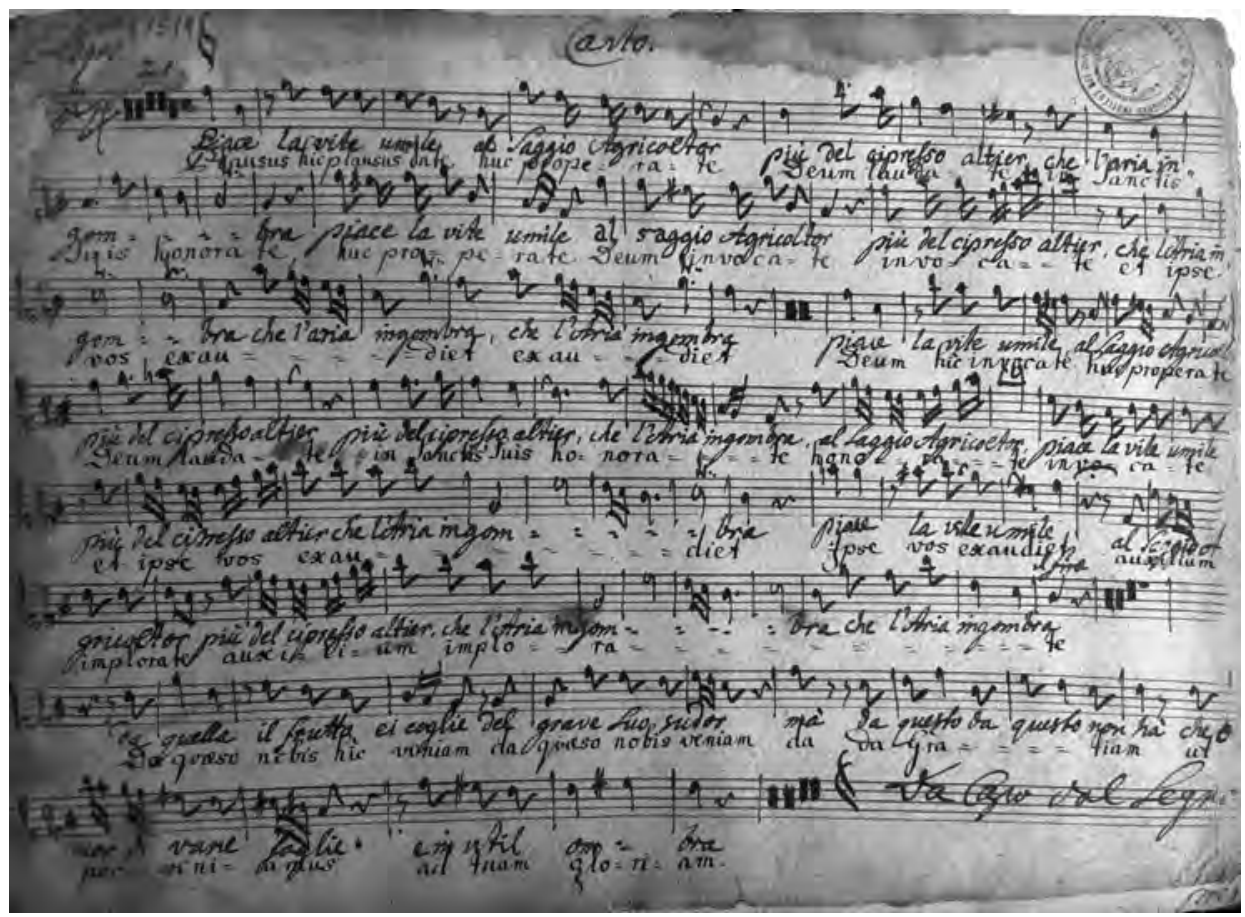

Figure 4 "Piace la vita umile" / "Plausus hic date" (Warsaw, Biblioteka Uniwersytecka, RM 5515; reproduced with kind permission).

In the discussed group of sources, we also find an example of a further stage in the travestimento spirituale: a composition written down only in the form of a contrafactum: to Baldassarre Galuppi's aria "Se perde il caro bene," from the opera L'Arminio (1747), another Eucharistic text has been added:22

Te Jesu mi praesentem,

Te Deum vere hic latentem,

$\mathrm{Te}$, Jesu, adoro sub paris specie.

Nunc Tuam, Jesu, oro immensam bonitatem ut Tua in aeternum fruer facie.

Contrafactum practice was obviously not limited to the Dominican order. It provided a universal modus procedendi for the period's many religious groups that conducted a dialogue with the secular culture of their time by musical means. ${ }^{23}$ However, the Silesian Dominicans participating in this process contributed to the dissemination of operatic

22 PL-Wu, RM 4374/5 [Mf 314]. Diplomatic title: "Aria de Venerabili | Canto Solo | Cythara Obl. | Violino | Viola | \& | Organo | Del Sigl | Galuppi | Rerum Fratris Pij Hancke | S. Ord. Praed."

${ }^{23}$ Burchard, Johann Adolf Hasse's Compositions; Byczkowska-Sztaba, Arie w zbiorze pocysterskim; Jeż, Reception of Neapolitan Music. 


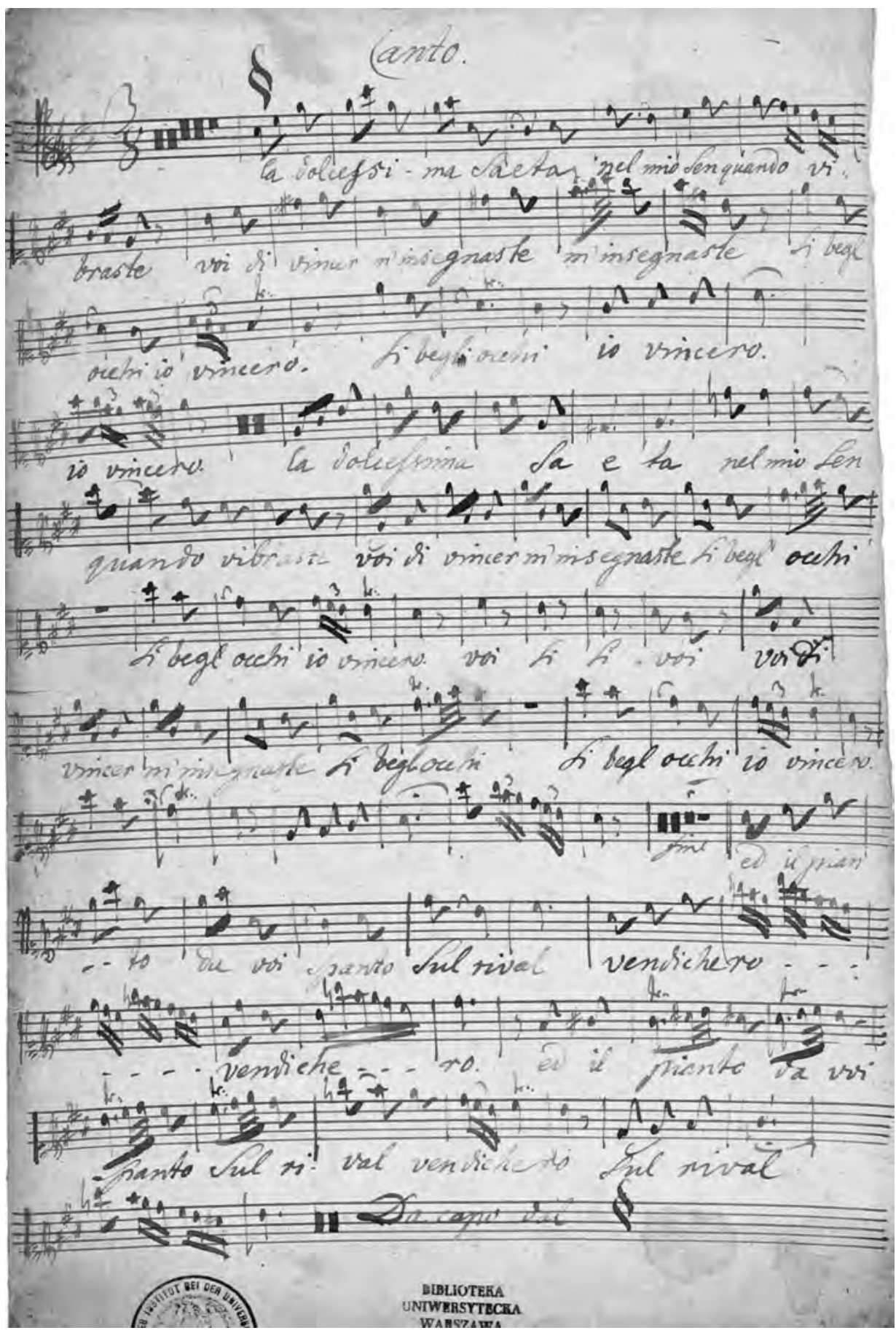

Figure 5a "La dolcissima saëtta" (Warsaw, Biblioteka Uniwersytecka, RM 5661; reproduced with kind permission). 


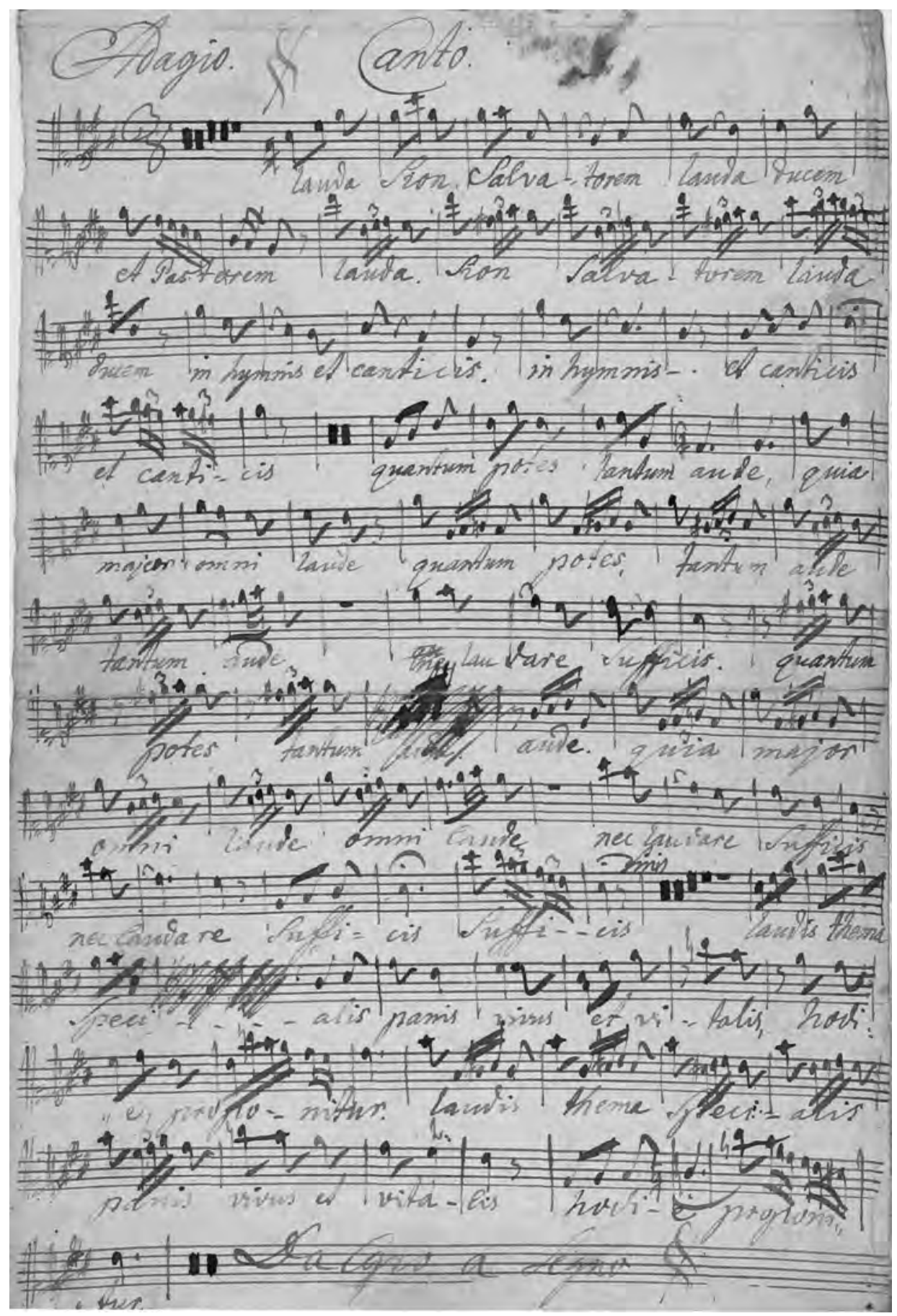

Figure 5b "Lauda Sion Salvatorem" (Warsaw, Biblioteka Uniwersytecka, RM 5661; reproduced with kind permission). 
repertoire in their centres. The arias they transported to the church, even after their clothing in new, religious texts, introduced qualities into the liturgy that were evidently secular. Was this process really a manifestation of concessions made to the fashion of the period and a testimony to spiritual weakness in the religious orders of that time? ${ }^{24} \mathrm{Or}$ did the post-Trent policy of adaptation produce effective results in practice even as late as the end of the eighteenth century and come to constitute a significant itinerary of the historical culture we are presently attempting to understand? If the language of religious and secular music was held in common at the time, it must consequently have moved listeners' emotions in the same manner, symbolically expressing the universal content of a culture extending from the sacrum to the profanum.

\section{Bibliography}

Bertolini, Manuel. "Censurare la musica congregazione oratoriana.” In La musica dei semplici: l'altra controriforma, edited by Stefania Nanni, 217-247. Rome: Viella, 2012.

Burchard, Maria. "Johann Adolf Hasse's Compositions in a Collection of Manuscripts from Silesia." In Johann Adolf Hasse und Polen: Materialien der Konferenz, Warszawa, 10-12 Dezember 1993, edited by Irena Poniatowska and Alina Żórawska-Witkowska, 154-155. Warsaw: Instytut Muzykologii Uniwersytetu Warszawskiego, 1995.

Byczkowska-Sztaba, Jolanta. “Arie w zbiorze pocysterskim w Krzeszowie.” In $X X V$ Sesja Naukowa: Muzyka oratoryjna i kantatowa w aspekcie praktyki wykonawczej, Wrocław, 7-8 września 1998 roku, 39-49. Zeszyt Naukowy Akademii Muzycznej im. Karola Lipińskiego we Wrocławiu, 74. Wrocław: Akademia Muzyczna im. Karola Lipińskiego we Wrocławiu, 1999.

Canones et decreta Concilii Tridentini: ex editione Romana a[nno] MDCCC XXXIV. repetiti; accedunt $S$. Congr. Card. Conc. Trid. interpretum declarationes ac resolutiones [...] assumpto socio Friderico Schulte. Edited by Aemilius Ludovicus Richter. Leipzig: Tauchnitius, 1853.

Dola, Kazimierz. Dominikanie w Nysie 1749-1810. Z dziejów kultury chrześcijańskiej na Śląsku, 52. Opole: Uniwersytet Opolski, Wydział Teologiczny, 2009.

Ferrari-Barassi, Elena. "Il madrigale spirituale nel Cinquecento e la raccolta Monteverdiana del 1583." In Congresso internazionale sul tema Claudio Monteverdi e il suo tempo: Venezia, Mantova e Cremona 1968, 211-252. Verona: Stamperia Valdonega, 1969.

Galiano, Carlo. "Bellarmino, i Gesuiti e la Musica in Italia fra Cinque- e Seicento." In Roberto Bellarmino, Arcivescovo di Capua, Teologo e Pastore della Riforma Cattolica: atti del Convegno Internazionale di Studi Capua 28 settembre - 1 ottobre 1988, edited by Gustavo Galeota, 365-457. Capua: Archidiocesi di Capua, Istituto superiore di scienze religiose, 1990.

${ }^{24}$ Hinnebusch, Dominikanie - krótki zarys dziejów, 226-228. 
Hauptman-Fischer, Ewa. "Mysterious Provenance and Uncommon Repertoire of the Collection of Notes Belonging to the Dominican Pius Hancke." Interdisciplinary Studies in Musicology 11 (2012): 155-167.

Hinnebusch, William A. “Dominikanie - krótki zarys dziejów.” In Dominikanie: Szkice z dziejów zakonu, 83-266. Poznań: W Drodze, 1986.

Jasiński, K. Summarium ordinationum capitulorum generaliom Ord. Praed. Kraków, 1638.

Jeż, Tomasz. "The Reception of Neapolitan Music in the Monastic Centres of Baroque Silesia." Studi pergolesiani / Pergolesi Studies 8 (2012): 341-368.

Libro primo delle laudi spirituali da diversi eccellenti e divoti autori, antichi e moderni composte. Le quali si usano cantare in Firenze nelle chiese doppo il Vespro o la Compieta a consolatione e trattenimento de' divoti servi di Dio. Con la musica propria a modo di cantare ciascuna laude, come si e usato de'gli antichi, et si usa in Firenze. Raccolte dal R. P. Serafino Razzi fiorentino, dellOrdine de' Frati Predicatori, a contemplatione delle monache, et altre persone divote. Nuovamente stampate, Con privilegii della illustrissima Signoria di Venetia et del Duca di Firenze, et di Siena. Venezia: Francesco Rampazetto, 1563.

Rostirolla, Giancarlo. "Aspetti di vita musicale religiosa nella chiesa e negli oratori dei padri Filippini e Gesuiti di Napoli a cavaliere tra cinque e seicento." In La musica a Napoli durante il Seicento, edited by Giulio D‘Amore, 643-704. Roma: Edizioni Torre d'Orfeo, 1987. 


\section{KONTRAFAKTURE OPERNIH ARIJ V BAROČNI GLASBI PRI DOMINIKANCIH V ŠLEZIJI}

\section{Povzetek}

Za ugotavljanje postopkov širjenja določenega repertoarja so še posebno dragocene zbirke, ki so jih ustvarjali oblikovalci tedanjega lokalnega glasbenega življenja. Ti so namreč po lastnem okusu in nagibih izbirali specifične elemente iz tedanje splošne glasbene ponudbe in jih nato ustvarjalno prilagajali lokalnim potrebam in zahtevam. Tak postopek tudi sicer predstavlja srž vsake žive glasbene kulture, obsega pa priredbe glasbenih del, prekomponirana dela in preobrazbe. Za razvejanost novoveških evropskih glasbenih tradicij so ti postopki ključnega pomena; pomembno so vplivali na kulturne prakse in oblikovanje ne le izvajalnega sloga, temveč tudi izvajalnih tehnik, glasbenih zvrsti in oblik.

Ena od oblik takih praks je bila tudi travestimento spirituale (duhovna preobleka), skozi katero je v liturgično glasbo prodrl tedaj priljubljeni operni repertoar. Ta način je bil izjemno priljubljen in razširjen v okviru glasbenih aktivnosti posameznih cerkvenih redov, še posebno tistih, ki so aktivno sodelovali v rekatolizacijskih reformah. Opravičevali so ga s potrebo po repertoarju, ki je po svoji privlačnosti enakovreden tistemu drugih veroizpovedi in ki je dobival vse večji pomen v medreligijskih soočanjih svojega časa.

Ta praksa je bila tudi ena najzanimivejših značilnosti redovnih krogov v Šleziji, deželi, kjer so bila verska nesoglasja še posebno izražena. Proces postopnih predelav repertoarja je jasno razviden iz glasbenih rokopisov zgodnjega osemnajstega stoletja, ki so nekoč pripadali dominikanskemu menihu Piusu Hanckeju. Deloval je v krajih, nemško imenovanih Breslau, Oppeln, Groß Stein in Neisse v Šleziji. Med njegovo bogato zbirko je tudi kontrafaktura petnajstih opernih arij Bononcinija, Fea, Galuppija, Giacomellija, Grauneja in Hasseja. Pojavlja se v različnih oblikah, ki dokumentirajo zaporedne faze predelav posvetne glasbe v novem liturgičnem kontekstu. Ti viri pričajo o pomembni poti širjenja opernega repertoarja $v$ tem obdobju ter o zelo zanimivem procesu radikalnih sprememb njegove družbene vloge, ki se v glasbenih zapisih kaže na različne načine.

Na podlagi teh bogatih in raznolikih virov lahko rekonstruiramo načine asimilacijskih procesov in nekatere vidike njihovega simboličnega pomena, ki so razvidni iz razmerja med izvirnim in novim besedilom. Hanckejeva prizadevanja za interpretatio Christiana delno osvetljujejo tudi duhovnost njegovega reda in njegovo kulturno identiteto, ki je temeljila na odprtem dialogu s posvetnimi tradicijami novoveške Evrope. Ta modus operandi je pomenil vsesplošno in temeljito sekularizacijo obravnavanega miljeja, ki je bila v svojem času pomembna sestavina lokalne in kontinentalne zvočne pokrajine. 